\title{
Floristic areas of the Middle Volga region: materials to the analysis
}

\author{
Stepan Senator*, Sergey Saksonov, and Viktoria Bondareva \\ Institute of Ecology of the Volga river basin of RAS, 445003, Komzina Str., 10, Togliatti, Russia
}

\begin{abstract}
The publication presents some quantitative characteristics of the 17 pre-selected floristic areas of the Middle Volga region (the total number of species, number of indigenous taxa and the number of differentiating species). Based on the available data, a linear regression is constructed, illustrating the relative dominance of allochthonous or autochthonous trends in the development of flora in the selected areas. The cluster analysis of the species lists of the floristic areas was completed, and then DCA-ordination of the selected areas was implemented. It is revealed that the forest-steppe areas of the Cis-Volga and Trans-Volga regions are situated by the level of species richness, and the number of species in the selected floristic areas is increasing from West and East towards the Volga.
\end{abstract}

For the territory of the Middle Volga region (within the borders of Samara oblast and Ulyanovsk oblast) to date floristic zoning is absent, which complicates the characterization of the distribution of vascular plants in the region and identification of patterns of their distribution. Previously, the working floristic zoning of the region was proposed [1]. This publication presents some quantitative characteristics of the selected areas and applied methodological practices.

There are 17 pre-selected districts, the analysis of the floristic specificity of which is made on the basis of indigenous species (table). Alien, extinct species and some species of the genera Alchemilla, Pilosella and Taraxacum didn't enter into consideration.

The work is based on the information stored in the Salix database, which contains information on nomenclature and distribution of species of plant within the Middle Volga region [2].

As it can be seen from the table, the number of indigenous species in the areas is almost comparable and varies from 1101 species (Zhigulevsky) to 541 (the Cheremshansky). With the exception of the South Volga, Bugulmino-Belebeevsky and Zasursky areas, information about the flora of which is very scarce.

The forest-steppe areas of the Cis-Volga and Trans-Volga regions are situated by the species richness and the number of species in the selected floristic areas is increasing from West and East towards the Volga. It should also be noted that the floristic richness of the selected areas is associated not so much with the general physiographic conditions and degree of territory development, but also with their size.

\footnotetext{
* Corresponding author: stsenator@yandex.ru
} 
Table. The main characteristics of the floristic areas of the Middle Volga region

\begin{tabular}{|c|c|c|c|c|c|}
\hline \multirow{2}{*}{ Floristic area } & \multirow{2}{*}{$\begin{array}{c}\text { Total } \\
\text { number of } \\
\text { species }\end{array}$} & \multicolumn{3}{|c|}{ Total number of indigenous taxa } & \multirow{2}{*}{$\begin{array}{c}\text { Number of } \\
\text { differentiating } \\
\text { species }\end{array}$} \\
\hline & & Families & Genera & Species & \\
\hline Zhigulevsky & 1358 & 107 & 443 & 1101 & 43 \\
\hline Sviyago-Usinsky & 1043 & 103 & 385 & 808 & 5 \\
\hline Syzransky & 822 & 96 & 357 & 706 & 10 \\
\hline Baryshsko-Inzensky & 721 & 101 & 336 & 643 & 9 \\
\hline Severo-Privolzhsky & 835 & 74 & 290 & 601 & 8 \\
\hline Zasursky & 299 & 66 & 180 & 276 & 4 \\
\hline Yuzhno-Privolzhsky & 187 & 40 & 121 & 175 & 1 \\
\hline Zasyzransky & 759 & 86 & 333 & 678 & 4 \\
\hline Soksky & 1156 & 104 & 433 & 978 & 22 \\
\hline Melekessky & 1296 & 95 & 384 & 758 & 3 \\
\hline Samaro-Kinel'sky & 683 & 92 & 343 & 611 & 6 \\
\hline $\begin{array}{l}\text { Bugul'minsko- } \\
\text { Belebeevsky }\end{array}$ & 132 & 43 & 101 & 118 & 0 \\
\hline Cheremshansky & 750 & 90 & 305 & 541 & 0 \\
\hline Akhtai-Mainsky & 873 & 96 & 346 & 697 & 0 \\
\hline Irgizsky & 369 & 53 & 186 & 327 & 30 \\
\hline Syrtovoy & 877 & 82 & 348 & 735 & 8 \\
\hline Volzhsky & 633 & 78 & 283 & 543 & 5 \\
\hline
\end{tabular}

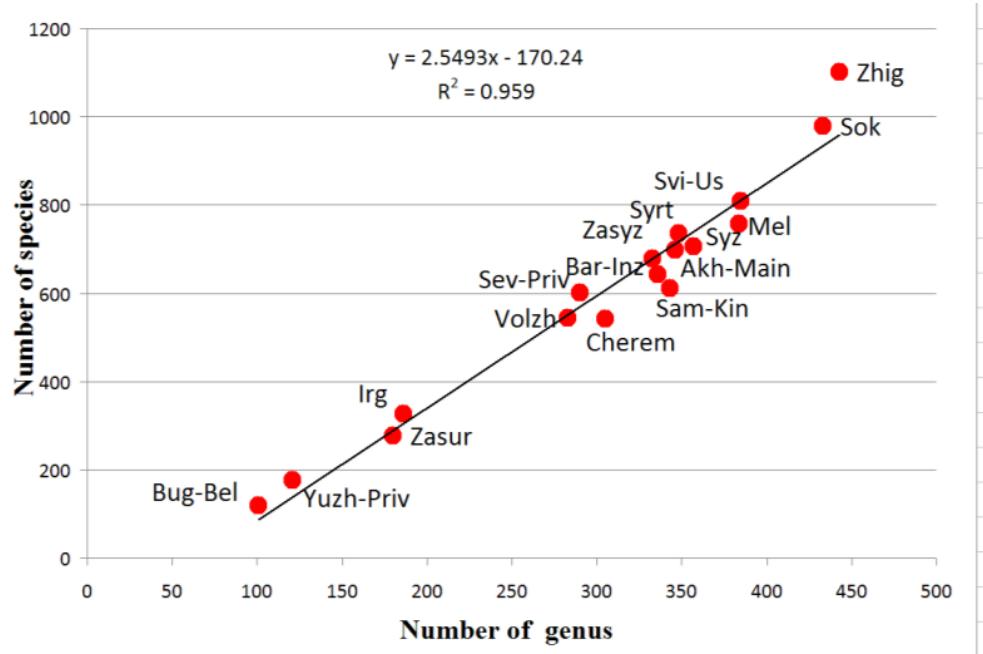

Fig. 1. The dependence of the number of species from the number of genus in the selected floristic areas

The number of identified at the moment of the differential species varies from 0 to Bugulmino-Belebeevsky, Cheremshansky and Ahty-Mainsky to 22 in Soksky, 30 in Irgizky and 43 in Zhigulevsky floristic areas. The total number of differential species is 156, which is about $10.5 \%$ of the sample. At the same time, 86 species are noted only in the Cis-Volga region, whereas 62 species are known solely in the Trans-Volga region.

According to the algorithm proposed by O.V. Khitun and A.A. Zverev [3], linear regression was constructed on the basis of the ratio of the number of species and genus, illustrating the relative dominance of allochthonous or autochthonous trends in selected 
floristic regions (Fig. 1). The coefficient of determination was very high in this case $(0,959)$.

Floristic lists for the areas were formed into a database on the platform of the program TURBOVEG [4]. Processing and analysis were conducted with the assistance of the JUICE 7.0. software package [5]. Using the PC-ORD 5.0. program, the data were subjected to cluster analysis that divided the sample into 3 groups (Fig. 2), and after that the DCAordination was conducted using the built-in JUICE program of the "Ordijuice" module from the R software package [6].

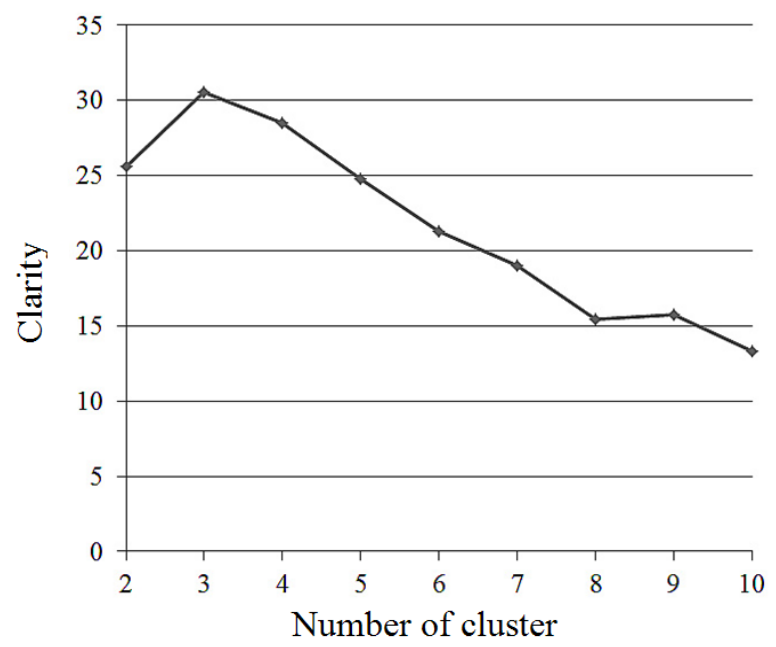

Fig. 2. The results of the cluster analysis of species-specific lists

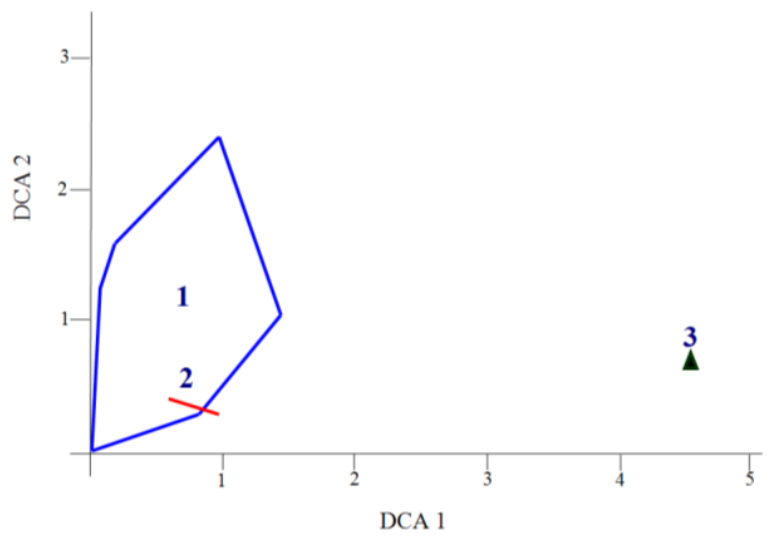

Fig. 3. DCA-ordination of the floristic areas of the Mid-Volga region

The first cluster unites almost all forest-steppe areas of the Cis-Volga and the TransVolga regions. The second cluster is the Zhigulevsky and Soksky floristic areas demonstrating the linkage between Zhiguli and the Urals, and the spread of most of the endemic species with the South Ural-Volga area is associated with these areas. The third cluster is Irgizky area, demonstrating a territory which is transitional to the dry steppe area (Fig. 3). 
Thus, the proposed work represents an attempt to understand and analyze the working of the scheme of floristic zoning of the region. The study itself is an exploratory one, and the achieved results are largely preliminary.

\section{References}

1. S.A. Senator, Biol Bull Russ Acad Sci., 44 (2017)

2. S. Senator, A. Klenin, S. Saksonov, Abstracts of the conference "Information Technologies in the Research of Biodiversity" (Irkutsk, 2018)

3. O.V. Khitun, A.A. Zverev, Vestnik Udmurstkogo Universiteta. Seriya Biologia. Earth science, 3 (2012)

4. S.M. Hennekens, J.H.J. Schaminée, J. Veg. Sci., 12 (2001)

5. L. Tichý, J. Veg. Sci., 13 (2002)

6. D. Zelený, L. Tichý, 18th Workshop of European Vegetation Survey in Rome. (Roma: La Sapienza Univerzita, 2009) 